\title{
Looking into Students' Willingness to Communicate: A Case Study in Mandarin Language Learning
}

\author{
Nuraini Jafri, Umi Kalthom Abd Manaf* \\ Faculty of Educational Studies, University Putra Malaysia, Serdang, 43400, Selangor Darul Ehsan, Malaysia
}

Received October 27, 2019; Revised December 2, 2019; Accepted December 24, 2019

Copyright $\bigcirc 2020$ by authors, all rights reserved. Authors agree that this article remains permanently open access under the terms of the Creative Commons Attribution License 4.0 International License

\begin{abstract}
This case study explores the students' willingness to communicate in Mandarin language. The learning of Mandarin as foreign language (FL) in Kolej Profesional MARA (KPM) Beranang has started since 2013. However, there have been some issues on students' willingness to communicate using Mandarin especially on students' reluctance to use the targeted language. Therefore, this research was aimed to explore students' willingness to communicate using Mandarin language in KPM Beranang. The research used a qualitative approach and the main data for the study was semi-structured interviews and observations. The researcher used Atlas.ti version 8.0 to analyze the data. The research findings showed that students' willingness to communicate by using Mandarin was only limited to greeting their teachers. It was found that students were not willing to use Mandarin in voicing out their opinions during the teaching and learning processes, not to mention when they are outside of the classroom context. The students did not have the confidence to use the targeted language and were not willing to communicate with strangers.
\end{abstract}

Keywords Willingness to Communicate, WTC, Mandarin Language, Foreign Language, FL

\section{Introduction}

China's rapid growth from a poor developing country to a major economic power has been very remarkable. Currently, China is the world's largest source of imports, largest merchandise trading partner of the United States and third-largest export market (Morrison, 2011). The emergence of China as one of the world economic powers has been spreading the demand of Mandarin language. The need to converse in the language especially in economical fields is extensively necessary for one to compete and survive in the ever-changing dynamic world.
The widespread demand of Mandarin language has also inevitably influenced Malaysia's education system to perceive the current global trend. Majlis Amanah Rakyat (MARA) as an important agency under the Ministry Rural Development is responsible for providing education facilities for Bumiputeras (Malaysian Malays and other indigenous people)

In carrying out its responsibility to produce first class human capital globally, MARA through Higher Education Division has adopted and adapted the Mandarin language into their education frameworks. The general aim of having Mandarin subjects in the curricula is to prepare the students with Mandarin language skills in order to produce marketable graduates, as these subjects are an added value towards the students' development.

Currently, there are two Mandarin courses being offered in all Kolej Profesional MARA (KPM) which are Mandarin Proficiency and Conversational Mandarin. Although the implementation of Mandarin subjects in KPM has been running for many years, since 2013, there however have been some issues raised especially regarding language learners' willingness to communicate.

During the learning processes, the students do have higher tendency in avoiding speaking Mandarin language. It has been observed that in Mandarin language classroom, although the students may participate in the class activities such as reading, writing and listening, they however, were not willing when it comes to speaking the language itself. This scenario has shown that students generally do not adopt active speech roles in the classroom, whereby they should be more actively involves in order to develop their communication and speaking skills (Burgoon, 1976).

The concerns mentioned do not only happened during the teaching and learning processes, but also has gone beyond the classroom settings. Most of the language teachers often encounter a common difficulty presented in language pedagogy. In this context, students were seen to be reluctant in conversing Mandarin language outside the classroom, whether with their friends and even with the 
teacher itself.

Based on the data gathered from the researcher's preliminary observation, it is found that most of the students will try to avoid from bumping into their Mandarin teachers outside of the classroom. One of the scenarios is illustrated as follows:

"The awkward situations happened when $I$, as a Mandarin teacher greeted a group of students in the hallway using a simple Mandarin sentences such as "你 们好! 你们要去哪里? ” (Hello! Where do you want to go?) and yet, the students seem to be startled and completely taken aback by the situation."

The learning of Mandarin does not only evolve in the classroom, but it goes beyond the classroom.

Therefore, in the case of foreign language learning, the students' unwillingness to communicate using the targeted language can lead to major issues especially in achieving the educational goal of Mandarin language subjects, which is to produce competent graduates, equipped with bilingual skills (including Mandarin) in order to withstand the global needs and challenges. Hence, it is empirical to explore deeply students' willingness to communicate in Mandarin.

\subsection{Research Purposes and Research Questions}

Based on the problem statements described earlier, the primary purposes of this research study were to explore students' willingness to communicate using Mandarin language in KPM Beranang. The research went for deeper exploration especially in term of their willingness to communicate in Mandarin not only in the classroom context, but also outside of the classroom settings.

Meanwhile the research purposes mentioned above has led to the following research questions, which were how willing are the KPM Beranang students to communicate using Mandarin? And to what extend are they willing to use the language?

\subsection{Significance of the Study}

There are several reasons that support the significance of this study. This study may contribute towards providing depth and better understanding in the implementation of Mandarin subject, particularly in Kolej Profesional MARA Beranang. The findings from it will helps to assist curriculum developers especially MARA Higher Education Division to review the curriculum by giving suggestions on how to make students more ready in using the language.

Last but foremost, the results of this study will help the teachers and educators uncover the mysteries on how to best understand and support the students in achieving the proficiency and reaching their language learning goals. This is also in line with the institutional philosophy especially in preparing and shaping the students to be holistic graduates.

\subsection{Research Limitation}

The current research is restricted to a number of limitations. This case study was conducted in KPM Beranang, therefore the results cannot be generalized to five other KPM across Malaysia which are KPM Ayer Molek, KPM Bandar Melaka, KPM Bandar Penawar, KPM Seri Iskandar and KPM Indera Mahkta.

Along with that, the research is restricted to students' willingness to communicate in Mandarin regardless their Mandarin cohort. Starting from intake June 2018, they are three different cohort of Mandarin language subject being offered in KPM Beranang, which are Mandarin Proficiency (new cohort), Mandarin (old cohort) and Conversational Mandarin (for Diploma in Landscape Horticulture cohort only).

\section{Literature Review}

In the current study, Mandarin language curriculum is designed especially for students who do not have any background in Mandarin and the native language of the students is Malay language.

Therefore, learning Mandarin in this study is described as foreign language learning. Mandarin as foreign language is a study of Chinese language (which is the Mandarin language) by non-native speakers. The learning of Mandarin language is not just about the phonological structure and orthographic feature, but it is beyond these alphabetic phonetic systems (Abro, Zhenfang \& Shabbir, 2014).

\subsection{The Nature of Mandarin Language}

The nature of Mandarin is an immensely complex language. It consists of Hanyu Pinyin (phonological structure) and Chinese characters (orthographic feature). Hanyu Pinyin is the Romanized alphabet system which consists of 21 initials, 36 finals, 411 possible combinations of initials and finals, and can up to thousands of syllables when applying the four tones $(\mathrm{Xu}, 2011)$.

Meanwhile, Chinese character is the Chinese writing system. Based on the List of Common Characters in Modern Chinese reported by Chinese State Language Commission and the Chinese State Education Commission (1988), there are more than 3500 characters are commonly being used (Chen, 1999).

On the other hand, it is viewed from the linguistic perspectives that listening, speaking, reading and writing skills are the way to learn Mandarin as foreign language (Spencer, 2015). According to the book of "Teaching Chinese as a Foreign Language: Theories and Applications" (2008), the authors emphasized on teaching listening and speaking skills through an interactive approach. The authors elaborate on the process of how the speaking skill derives from listening, and at the same time enhance the 
students' ability of reading, and later followed by writing skills.

\subsection{Communicative Language Teaching}

According to Richards \& Rodgers (1985), under the umbrella of foreign language learning, there are three terms that need to be understand, which are approach (related to the beliefs and theories on the language), procedure (focuses on the techniques and practices inside the language classroom) and design (more connected to the teaching materials being used such as books, etc.). Under this section, the researcher tries to investigate and understand theories related to the foreign language learning.

The research on foreign language is a dynamic subject as it keeps on evolving especially in helping the learners to grasp the targeted language comprehensively and at the same time, able to achieve their academic goals effectively (Richards \& Theodore, 2001). Among of the focuses are the exploration on language pedagogical trends including Cognitive Approaches, Audio lingual Approach, Grammar Translation Method and communicative pedagogy (Larsen-Freeman, 2000). However, in the $20^{\text {th }}$ century, there are two main language approaches became a prominence study which are Grammar Translation Method and Communicative Language Teaching (Hinkel, 2005).

As the Grammar Translation Method relatively focuses on thorough analysis in terms of language usage accuracy and error-free grammar rules, the Communicative Language Teaching contrarily sees language as tool to maintain the social relations in daily life communications (Hendrickson, 1991). According to the American Council on the Teaching of Foreign Language's National Standards (1999), communication is conceptualized into three modes which are interpersonal, interpretive and presentational. The learners are said to be in the interpersonal communication mode when they engaged in a conversation and interpret other's speech and presenting their own view of points. These three communication modes can be effectively working under the framework of Communicative Language Teaching.

Numbers of linguistics and educators foresee the need to emphasize communicative proficiency in language teaching, rather than the mastery of structures (Widdowson, 1978; Candlin, 1981; Richards \& Rodgers, 1986; Galloway, 1993). It is very important to equip the learners as communicative competence, in which Hymes (1972) defined as the ability to determine when to speak or not to speak, with whom, where, when, talk about what and in what manner (cited in Richards \& Rodgers, 2001).

Although the origin of Communicative Language Teaching is said to be developed from the second language theories (Savignon, 1987; 1991), multiple educators (such as Widdowson, 1978; Johnson and Morrow, 1981; Richards and Rodgers, 1986; Larsen-Freeman, 1986 etc.) significantly recognized the application of Communicative Language Teaching in learning foreign language field areas. Among major characteristics of Communicative Language Teaching are the focus towards function or use of the language rather than grammatical structure (Larsen-Freeman, 1986), the emphasized on fluency and accuracy to engaged in language use (Brown, 1994) and the teaching of grammar is still needed but less systematically and more innovative approaches (Thompson, 1996). On top of that, Communicative Language Teaching also focuses on providing meaningful learning opportunities especially in real-life situations and real communication (Johnson and Morrow, 1981) and promoting learners' confidence in all four skill areas of listening, speaking, reading and writing, and not limited to oral proficiency only (Celce-Murcia, 1991; Savignon, 2002).

Hence through the humanistic approach of Communicative Language Teaching, the language learning focuses on task-oriented and student-centered language teaching practice to provide the students with a comprehensive use of the targeted language (Richards, 2006).

\subsection{Willingness to Communicate}

The concept of willingness to communicate (WTC) was originated from the notion of "unwillingness to communicate" which is a work of Burgoon in 1976 (McCroskey \& Richmond, 1982, 1987; McCroskey \& Baer, 1985). There are two basic constructs that is formulated to relate to actual communicate behavior, which are approach-avoidance and reward. However, the finding of her construct cannot provide support for or against in determining one's being willing or unwilling to communicate.

In 1985, McCroskey and Baer refined the work of Burgoon and changed the construct to a positive stance "willingness to communicate (WTC)". The new construct also incorporates the elements found in the work of Mortensen, Arntson and Lustig (1977) on verbal behavior and McCroskey and Richmond's work (1982) on shyness (McCroskey \& Baer, 1985; MacIntyre, Dornyei, Clement $\&$ Noels, 1998).

Although initially WTC was used to first language learners' willingness to communicate, however it can also be applied to second or foreign language learners (MacIntyre et al., 1998, 2007). Later in 1998, MacIntyre et al. proposed a new "heuristic model" that presents the variable which has impact towards second language WTC. According to MacIntyre (1998), the new refined model is defined as "a readiness to enter into any discourse at any particular time with a specific person(s) using second or foreign language.

Based on the Pyramid Model of WTC (MacIntyre, 1998), the actual use of second language (in this context: foreign language) is at the Layer I, which is dependent on the 
willingness to communicate in Layer II. While at the middle layer of the model (Layer III-V), it focuses on various aspects that might affect the usage of a second language such as self-confidence, motivation, affective-cognitive context etc. At the most bottom layer of the pyramid, it highlights on the social and individual context.

MacIntyre et al. $(1998,2001)$ rationalized the pyramid by making distinction of second language WTC inside and outside of the classrooms as the learning of second or foreign language usually takes place inside the classrooms. The WTC model incorporates the four language skills (listening, speaking, reading and writing), and scenarios inside and outside of language classrooms (MacIntyre et al., 2001). The model also taken into account the variables of communication apprehension, motivation, self-perceived communication competence as among the strongest points in assessing one's willingness to communicate using second or foreign language.

\subsection{Theoretical Underpinnings}

Based on all the theories discussed, the theoretical framework for this case study context comprises of various importance elements from the Mandarin language learning as foreign language and students' willingness to communicate using the targeted language in KPM Beranang.

The literature reviews described four skills that Mandarin language learners need to gain throughout the learning which are listening, speaking, reading and writing. This is also in line with the characteristics of Communicative Language Learning, which one of the major characteristics focuses on the language learners' development on listening, speaking, reading and writing skills (Celce-Murcia, 1991; Savignon, 2002). However, in the present research, the writing skills will not be taken into account as the curriculum context of Mandarin subjects in KPM Beranang does not include writing skills as their curriculum educational objectives. Hence, the language skills that learners need to be able to demonstrate are listening, speaking and reading skills.

Meanwhile, the theory of Willingness to Communicate (MacIntyre, 1998) will be used as a guidance to describe the students' willingness to communicate using Mandarin language in KPM Beranang.

\section{Methodology}

The current study aimed to investigate KPM Beranang students' willingness to communicate in Mandarin language. In the direction towards searching the answers for this research, the study was conducted qualitatively. Denzin and Lincoln $(1994 ; 2003)$ summarized that qualitative researchers study things in their natural settings, attempting to make sense of, or interpret, phenomena in terms of the meanings people bring to them. Hence, through qualitative research, the researcher able to get in depth understanding towards the scenarios and the desired results.

Meanwhile, case study design was chosen for this research design. According to Stake (1995), case study design is the best way to help the researcher in describing and understanding an individual case, which in this particular research is a case of foreign language learners' willingness to use the targeted language in one particular setting. In fact, Lincoln and Guba described case study as "holistic and lifelike" as through this research design it presents a picture credible to the actual informants in a setting and can easily be cast into the 'natural language' of the audiences that involved.

\subsection{Population and Sampling}

The current research was conducted at KPM Beranang, Selangor Darul Ehsan. During the data collection period, KPM Beranang offered Mandarin 2, Mandarin 3, Mandarin Proficiency 1, Mandarin Proficiency 2 and Conversational Mandarin 2. There were 375 students registered for Mandarin classes. Through purposive sampling, only five students from total students registered for Mandarin classes were chosen as the research informants. Each informant represents each Mandarin level.

This case study was conducted at Kolej Profesional MARA Beranang, Selangor Darul Ehsan. Altogether there were 1350 students in KPM Beranang, and there were only 375 students who are currently taking Mandarin language subjects. These groups of students were the ones that have been observed during the class sitting observations.

According to Yin (2011), "The participants or sources of data is selected based on their anticipated richness and relevance of information in relation to the study's research questions" (Gentles, Charles \& McKibbon, 2015; Yin 2011). Therefore, it is crucial to select informants who would be able to impart significant insights on their experiences on the Mandarin language subject implementation in Kolej Profesional MARA Beranang as their role being the informants will provide comprehensive information in order to answer the purpose of this study.

\subsection{Data Collection Methods and Data Analysis Procedures}

The data from the current case study were collected through semi-structured interview and observations. The main qualitative data for this research was collected from the semi-structured interview. The researcher used Patton's approaches in designing the interview protocols (2001). The multiple interview protocols will be constructed separately for each student. These protocols will be reviewed by the experts especially relating to the aspects of 
clarity, redundancy, readability and completeness. The experts should be the one who are expert in the field of second language acquisition curriculum, particularly Mandarin language subjects. The experts' reviews will ensure the interview questions are more comprehensible and appropriate to the informants.

Besides that, data collection for this case study also were collected from the observation method. The observation phase was conducted repeatedly within the eight instructional weeks. Through this method, it does provide researchers with ways to check for non-verbal expression of feelings, observing the conversation in terms of contents, who speaks to whom, who listens, silences and how that role affects the environment, and what one says or thinks (Schmuck, 1997).

In this qualitative case study design, the data analysis is called the process of making sense of the data received (Miles \& Huberman, 1994). It is very crucial to have a system in analyzing the data in order to produce efficient results of the data analysis. According to Cresswell (2014), data analysis procedures include coding the data, reducing the data into meaningful segments and combining the codes into broader themes. Thus, the research was analyzed by following a general inductive data analysis format. Through Atlas.ti version 8.0, all the data were coded, categorized and thematized.

\subsection{Researcher's Role}

Lincoln and Guba (1985) described researcher as an instrument as the researcher himself or herself can be responsive to the environment, able to adopt the techniques to the particular circumstances, capable to increase or expand his or her understanding through observation to nonverbal aspects and explore anomalous responses.

In this context, the researcher able to explore and identify various conditions of the implementation of Mandarin language subjects' curriculum in KPM Beranang, which will then enhance the researcher's understanding and insights from the perspectives of the informants rather than the researcher.

\subsection{Establishing Trustworthiness}

Qualitative research design uses a naturalistic approach that allows the researcher to understand the phenomena in context-specific settings, such as "real world setting where the evaluator does not attempt to manipulate the phenomenon of interest" (Patton, 2001). In this context, the researcher himself/herself is the instrument of this study.
The credibility of this qualitative study depends on the ability and effort of the researcher. Hence, it is very crucial to establish the trustworthiness of the data collected.

In this case study, the interview questions inventory will be submitted to the supervisor to ensure the research objective and its theme is aligned with the research questions. The supervisory committees will also review the interview questions pertaining to its language, wording and relevance. At this point of process, the supervisors' reviews and evaluations is also considered as a form of validity.

Besides that, the research also developed an audit trail from the beginning till the end of the research as an evidence to prove its trustworthiness (Creswell and Miller, 2000). All the raw data, notes from interview and observation sessions, test scores and attendance records will be kept for cross-checking the inquiry process. Thus, making the audit process is beneficial for the researchers who seek validation for their works.

\section{Results and Discussion}

The research questions looked into the students' willingness to communicate using Mandarin in overall context and to what extent they are willing to use the targeted language comprehensively. Under these research questions, there were three themes that can be identified during the interview sessions, and for certain themes, field notes from the observation data were served as the supporting data. The themes are as follows: 1) Willingness to Use the Language, 2) Confidence and 3) The Influence Language Teachers.

\subsection{Willingness to Use the Language}

Under this theme, the researcher ought to explore the students' oral efficiency in terms of their willingness to use Mandarin in daily conversation and as a means of communication. The exploration involved the regular setting of the students' daily life, up to unfamiliar environments in several events such as using the language to converse with strangers and buying things at the market.

In the regular setting of the students' daily life, the informants showed their willingness to use the language to greet their Mandarin teacher if they bump into their teacher outside of the classroom. This is proven by the following statements: 
Table 1. Informants' responses on their willingness to greet teachers

\begin{tabular}{|c|c|c|}
\hline Informant & Data Extract (verbatim) & Coded for \\
\hline $\mathrm{P} / \mathrm{M} 3 / \mathrm{F} / 001$ & $\begin{array}{c}\text { "I would greet her in Mandarin like Zaoshang } \\
\text { hao, laoshi!" }\end{array}$ & [willingness] [greet teacher] [positive] \\
\hline $\mathrm{P} / \mathrm{M} 2 / \mathrm{F} / 002$ & $\begin{array}{l}\text { "I will greet her in Mandarin... Zaoshang hao, } \\
\text { laoshi!" }\end{array}$ & [willingness] [greet teacher] [positive] \\
\hline $\mathrm{P} / \mathrm{CM} 2 / \mathrm{M} / 003$ & $\begin{array}{l}\text { "I will go and greet her because practice makes } \\
\text { perfect. I will say Nihao, laoshi! " }\end{array}$ & [willingness] [greet teacher] [positive] \\
\hline $\mathrm{P} / \mathrm{MP} 2 / \mathrm{M} / 005$ & "I will greet her but only simple greetings " & $\begin{array}{l}\text { [willingness] [greet teacher] [partial } \\
\text { positive] }\end{array}$ \\
\hline $\mathrm{P} / \mathrm{MP} 1 / \mathrm{M} / 004$ & $\begin{array}{l}\text { "Hmm... I will greet her in English only because } \\
\text { I am afraid my pronunciation is not correct." }\end{array}$ & [willingness] [greet teacher] [negative] \\
\hline
\end{tabular}

From the data stated in Table 1, majority of the informants positively willing to greet their teachers outside of the classroom, and informant (P/MP2/M/005) specifically mentioned that she will greet her teacher in simple greetings only. Meanwhile, only one informant (P/MP1/M/004) reacted differently as he will only greet his teacher in English because he afraid will mispronounce the words.

Going deeper in seeking the students' willingness especially in expressing one self's thought, the researcher attempted to ask the students whether they are willing to use the language to express their thoughts or feelings. Majority of the informants are not willing to express their thoughts publicly, even in the classroom contexts. In this scenario, informants were asked whether they are willing to express their opinion in Mandarin class using Mandarin.

Table 2. Informants' responses on their willingness to express opinion

\begin{tabular}{|c|c|c|}
\hline Informant & $\begin{array}{c}\text { Data Extract } \\
\text { (verbatim) }\end{array}$ & Coded for \\
\hline $\mathrm{P} / \mathrm{M} 3 / \mathrm{F} / 001$ & $\begin{array}{c}\text { "Hmm, it's a bit } \\
\text { hard. No! " }\end{array}$ & $\begin{array}{c}\text { [willingness] [express } \\
\text { opinions] [negative] }\end{array}$ \\
\hline $\mathrm{P} / \mathrm{M} 2 / \mathrm{F} / 002$ & "No!" & $\begin{array}{c}\text { [willingness] [express } \\
\text { opinions] [negative] }\end{array}$ \\
\hline $\mathrm{P} / \mathrm{CM} 2 / \mathrm{M} / 003$ & "For now, a big & $\begin{array}{c}\text { [willingness] [express } \\
\text { opinions] [negative] }\end{array}$ \\
\hline $\mathrm{P} / \mathrm{MP} 1 / \mathrm{M} / 004$ & "No way" & $\begin{array}{c}\text { [willingness] [express } \\
\text { opinions] [negative] }\end{array}$ \\
\hline $\mathrm{P} / \mathrm{MP} 2 / \mathrm{M} / 005$ & $\begin{array}{c}\text { "I don't think so. } \\
\text { No. " }\end{array}$ & $\begin{array}{c}\text { [willingness] [express } \\
\text { opinions] [negative] }\end{array}$ \\
\hline
\end{tabular}

The exploration on students' willingness to use the language goes beyond the classroom settings, up to the extent outside of their regular settings. It is aimed to gain understanding on their readiness to use Mandarin publicly as simple as greetings stranger to buying things. However, majority of the students are reluctance to use the language outside of their comfort zone. Among the reasons given were being shy and afraid. This is proven by the following statements:
Table 3. Informants' responses on their willingness to use Mandarin outside classroom contexts

\begin{tabular}{|c|c|c|}
\hline Scenario & Informant & Data Extract (verbatim) \\
\hline \multirow{4}{*}{$\begin{array}{c}\text { Greetings } \\
\text { strangers }\end{array}$} & $\mathrm{P} / \mathrm{M} 3 / \mathrm{F} / 001$ & "I don't think so ". \\
\cline { 2 - 3 } & $\mathrm{P} / \mathrm{M} 2 / \mathrm{F} / 002$ & "No way!" \\
\cline { 2 - 3 } & $\mathrm{P} / \mathrm{CM} / \mathrm{M} / 003$ & "Of course, no " \\
\cline { 2 - 3 } & $\mathrm{P} / \mathrm{MP} 1 / \mathrm{M} / 004$ & "No". \\
\cline { 2 - 3 } & $\mathrm{P} / \mathrm{MP} 2 / \mathrm{M} / 005$ & "No because I'm shy ". \\
\hline \multirow{4}{*}{$\begin{array}{c}\text { Buying } \\
\text { things }\end{array}$} & $\mathrm{P} / \mathrm{M} 3 / \mathrm{F} / 001$ & $\begin{array}{c}\text { "Not for now because I } \\
\text { am really afraid". }\end{array}$ \\
\cline { 2 - 3 } & $\mathrm{P} / \mathrm{M} 2 / \mathrm{F} / 002$ & "No". \\
\cline { 2 - 3 } & $\mathrm{P} / \mathrm{CM} 2 / \mathrm{M} / 003$ & "No". \\
\cline { 2 - 3 } & $\mathrm{P} / \mathrm{MP} 1 / \mathrm{M} / 004$ & "No ". \\
\cline { 2 - 3 } & $\mathrm{P} / \mathrm{MP} 2 / \mathrm{M} / 005$ & "No ". \\
\hline
\end{tabular}

From the above findings, it can be summarized that majority of the informants were only comfortable and willing to use Mandarin with their teachers only. They, however, were not willing to use the language not only to voice out their opinions, also not to use the language outside of their normal settings which is their classroom settings.

\subsection{Confidence}

This theme is derived from the informants owns perspectives especially in using Mandarin language. All informants are not comfortable to start a conversation in Mandarin. They lack confidence to utilize their Mandarin language.

Table 4. Informants' responses on their confidence to use Mandarin

\begin{tabular}{|c|c|}
\hline Informant & Data Extract (verbatim) \\
\hline P/M3/F/001 & $\begin{array}{c}\text { "I maybe a little bit afraid. I do not know } \\
\text { the words". }\end{array}$ \\
\hline P/M2/F/002 & "I am not that confident". \\
\hline P/CM2/M/003 & $\begin{array}{c}\text { Not confidence. Not comfortable because } \\
\text { I never speak to anyone in Mandarin". }\end{array}$ \\
\hline P/MP1/M/004 & "No. Not prepared". \\
\hline P/MP2/M/005 & $\begin{array}{c}\text { "Ït is not possible for me to converse in } \\
\text { Mandarin". }\end{array}$ \\
\hline
\end{tabular}


The data above showed that students are either shy or scared to use the language in conversation or communicating with others. Their lack of confidence and motivation to apply and practice the language in daily life are among of the other issues that needed attention from the stakeholders including teachers, curriculum policymakers and school administrators.

According on the fourth layer of the Pyramid Model proposed by MacIntyre (1998), the motivational propensities are among the aspect that affect language learners' willingness to communicate. The motivational propensities are interpersonal motivation, intergroup motivation and self-confidence.

Hence, through thorough curriculum review especially in considering the integration of Chinese cultural elements and changing from examination-based assessments towards active language practical assessments (as discussed in the previous part), students' willingness to use Mandarin can be further improved.

\subsection{The Influence of Language Teachers}

The influence of language teachers is considered as an emerging theme in this research study. The current research focuses on describing the students' willingness to communicate using Mandarin. However, during the exploration of data, it is profound that students are more likely to engage in learning Mandarin due to the significant attribute of language teachers. Students are positively ready towards responding to their teachers' instructions. This can be supported by the following excerpts:

Table 5. Informants' responses regarding their language teachers

\begin{tabular}{|c|c|}
\hline Informant & Data Extract (verbatim) \\
\hline $\mathrm{P} / \mathrm{M} 3 / \mathrm{F} / 001$ & $\begin{array}{c}\text { "I really like my Mandarin teacher. She's } \\
\text { happy go lucky. She makes me want to } \\
\text { enter Mandarin class with her fun } \\
\text { teaching". }\end{array}$ \\
\hline $\mathrm{P} / \mathrm{M} 2 / \mathrm{F} / 002$ & $\begin{array}{c}\text { "Yes! My teacher really helps me in class. } \\
\text { She encourages me to speak and she did } \\
\text { not mad if I make mistakes". }\end{array}$ \\
\hline $\mathrm{P} / \mathrm{MP} 2 / \mathrm{M} / 005$ & $\begin{array}{c}\text { "My teacher is very good. I love to learn } \\
\text { with her. I never missed her class". }\end{array}$ \\
\hline
\end{tabular}

Therefore, the above findings emphasized the role of language teachers in attracting and influencing students' willingness to use Mandarin. Teachers' attributes play an important role in the foreign language learning. According to Dornyei and Csizer (1998), there are ten guidelines listed to motivate students, which three of the commandments focus on teachers' pedagogical practices. Based on the guidelines, teachers are encouraged to set a personal example with teacher's own behavior such as enthusiasm in teachings, along with creating a conducive and relaxed environment in the classroom. Students' ability to grasp the language will be greatly enhanced when the students feel a low level of anxiety (Krashen,
1982, 1985). On top of that, building a good relationship with the learners will greatly enhance students' readiness especially in entering the class and engaging with the teachers inside and outside of the classroom.

Besides that, it is crucial for the teachers to reflect their own pedagogical practices. The above findings also mentioned the participants are fond of their teachers because of the teachers' pedagogical practices. Foreign language teachers need to be able to manage their own learning, from planning the teaching to the implementation of learning process and evaluating the learners' learning outcomes (Mardia, 2014). These types of competencies should be owned by teachers to strive successes in their teaching and learning processes.

\section{Conclusion}

In a conclusion, it can be summarized that students' willingness to communicate using Mandarin were still situational. The analyzed findings showed that students were only willing to communicate their own language teachers using simple greetings. However, when being asked to voice out their opinions or using the language outside of the classroom settings, they were not confident and unwilling to use the language.

Hence in the current study, the willingness to use the language in a broader context is an important issue that needs to be taken into account specially to enhance students' readiness in using Mandarin to converse and communicate with others. Fluency in willingness to use the language is described as the natural language use when a speaker engages in a meaningful interaction and maintains the ongoing communications (Gang \& Xiaochun, 2015).

Hence, there is a need to revise the assessment from examination oriented to more practical language learning, which is also in line with the Communicative Language Teaching approaches. For instance, instead of having an examination-based assessment, learning opportunities should be more in a real context setting such as project-based learning, problem-based learning etc.

According to Lee \& VanPatten (2003), foreign language learning requires using the language to interpret and express real-life circumstances, especially to provide the learners with learning opportunities. Engaging in an active learning environment, learners are said to be more responsible for their learning and able to enhance their willingness to communicate using the targeted language (Ballman, 2001).

On top of that, it is very crucial for the teachers to equip themselves with the knowledge especially in the area of teaching pedagogical competencies. Teachers' pedagogical practices play an important role in enhancing the students' willingness to use the targeted language especially in terms of considering inculcating the approaches of Communicative Language Teaching. Besides being able to 
enhance the teachers' professionalism, at the same time students' willingness to communicate in Mandarin also can be enhanced.

\section{REFERENCES}

[1] Abro, M., Zhenfang, L. \& Shabbir, R. (2014). Mandarin: Conquering the Language Classrooms around the World. American International Journal of Contemporary Research, 4 (3), 48-54.

[2] Ballman, L. T., Liskin-Gasparro, E. J. \& Mandell, B. P. (2001). The communicative classroom (Volume III). Boston: Heinle \& Heinle

[3] Baskarada, S. (2014). Qualitative Case Study Guidelines. The Qualitative Report, 19 (40), 1-18.

[4] Brown, H. (1994). Teaching by principles - An interactive approach to language pedagogy. Pretinence Hall.

[5] Brown, H. D. (2000). Principles of Language Learning and Teaching (4th Edition). New York, NY: Longman.

[6] Burgoon, J. K. (1976). The unwillingness to communicate scale: Development and validation. Communication Monographs, 43 (1), 60-69.

[7] Celce-Murcia, M., Doenyei, Z. \& Thurrell, S. (1997). Direct approaches in L2 instruction: A turning point in Communicative Language Teaching? TESOL Quarterly, 31 (1), 141-152.

[8] Chen, P. (1999). Modern Chinese: History and Sociolinguistics. Cambridge: Cambridge University Press.

[9] Creswell, J. W. (2014). Research design: Qualitative, quantitative and mixed methods approaches (4th edition). Thousand Oaks, California: SAGE Publications.

[10] Denzin, N. K. \& Lincoln, Y. S. (2003). The landscape of qualitative research: Theories and issues (2nd edition). London: SAGE Publications.

[11] Dolan, M. W. (1985). Integrating listening, speaking, reading and writing in the classroom. Language Arts Journal of Michigan, 1 (1), 7-12.

[12] Dornyei, Z. \& Csizer, K. (1998). Ten commandments for motivating language learners: results of an empirical study. Language Teaching Research, 2 (3), 203-229.

[13] Ellis, R. (2004). The definition and measurement of explicit knowledge. Language Learning, 54, 227-275.

[14] Ellis, R. (2008). The Study of Second Language Acquisition. Oxford: Oxford University Press.

[15] Ellis, R. (2012). Language teaching research and language pedagogy. Chichester: Wiley-Blackwell.

[16] Everson, M. E. \& Yun, X. (2008). Teaching Chinese as a Foreign Language: Theories and Applications. Cheng \& Tsui Publisher.

[17] Fitzpatrick, J., Sander, J. \& Worthen, B. (2012). Program Evaluation: Alternative approaches and practical guidelines.
Boston, Mass: Pearson.

[18] Galloway, A. (1993). Communicative language teaching: An introduction and sample activities. Center for Applied Linguistics, ERIC Digest.

[19] Gentles, S. J., Charles, C., Ploed, J. \& McKibbon, K. (2015). Sampling in Qualitative Research: Insights from an Overview of the Methods Literature. The Qualitative Report. 20 (11), 1772-1789.

[20] Grinin, L., Tsirel, S. and Korotayev, A. (2014). Will the explosive growth of China continue? Technological Forecasting and Social Change, 95, 294-308.

[21] Hendrickson, J. M. (1991). On communicative language teaching. Hispania, 74 (1), 197-198.

[22] Hinkel, E. (2005). Handbook of research in second language teaching and learning. Mahwah, NJ: Lawrence Erlbaum Associates.

[23] Hymes, D. H. (1972). Models of interaction of language and social life. Directions in sociolinguistics: The ethnography of communication. New York: Holt, Rineheart \& Winston. pp. 35-71.

[24] Krashen, S. (1982). Principles and Practice in Second Language Acquisition. Oxford: Pergamon Press.

[25] Krashen, S. (1985). The Input Hypothesis: Issues and Implications. Harlow: Longman.

[26] Larsen-Freeman, D. (2000). Techniques and principles in language learning. New York: Oxford University Press

[27] Liu, X. (2006). Hanyu Zuowei Di ‘Er Yuyan Jiaoyu Jianlun. Beijing: Beijing Language and Culture University Press.

[28] MacIntyre, P. D. (2007). Willingness to communicate in the second language: Understanding the decision to speak as a volitional process. The Modern Language Journal, 91, 564-676.

[29] Mardia, R. (2014). Professional Competence, Pedagogical Competence and the Performance of Junior High School of Science Teachers. Journal of Education and Practice, 5 (9), 75-80.

[30] McCroskey, J. C. \& Baer, J. E. (1985). Willingness to communicate: The construct and its measurement. Paper presented at the Speech Communication Association Convention, New Orleans.

[31] McCrosket, J. C. \& Richmond, V. P. (1982). Communication apprehension and shyness: Conceptual and operational distinctions. Communication Research Reports, 5,108-113.

[32] McCroskey, J. C. \& Richmond, V. P. (1987). Willingness to communicate. In J. C. McCroskey \& J. A. Daly (Eds.), Personality and interpersonal communication. Newbury Park, CA: Sage.

[33] Merriam, S. B. (2009). Qualitative Research: A Guide to Design and Implementation (3rd edition). San Francisco: Jossey-Bass Publishers.

[34] Moeller, A. J. \& Catalano, T. (2015). Foreign language teaching and learning. In J. D. Wright (Ed.). International Encyclopedia for Social and Behavioral Sciences (2nd 
edition), 9, 327-332. Oxford: Pergamon Press.

[35] Morrison, W. M. (2011). China-U.S. Trade Issues. Washington, D.C.: Library of Congress, Congressional Research Service.

[36] Patton, M. Q. (2001). Qualitative evaluation and research methods (3rd edition). Thousand Oaks, CA: SAGE Publications.

[37] Poole, F. \& Sung, K. (2015). Three approaches to beginning Chinese instruction and their effects on oral development and character recognition. Eurasian Journal of Applied Linguistics, 1, 59-75.

[38] Richards, J. C. \& Theodore, R. (2001). Approaches and Methods in Language Teaching (2nd edition). New York: Cambridge University Press.

[39] Sauvignon, S. J. (2001). Communicative Language Teaching. Teaching Foreign Languages, 26 (4), 235-242.

[40] Spencer, W. A. (2015). Mandarin Chinese as a second language: A review of literature. Honor Research Project, 210, 1-47.

[41] Stakes, R. E. (1995). The art of case study research. Thousand Oaks, California: SAGE Publications.

[42] Sun, C. (2006). Chinese: A linguistic introduction. Cambridge: Cambridge University Press.

[43] Tannen, D. \& Saville-Troike, M. (1985). Perspectives on silence. Norwood, N.J: Ablex Pub. Corp.

[44] Tsai, R. (2011). Teaching and learning the tones of Mandarin Chinese. Scottish Languages Review, 24, 43-50.

[45] Tsung, L. T. \& Cruickshank, K. (2012). Teaching and learning Chinese in global contexts: CFL Worldwide. London: Continuum.

[46] Wang, Y., Jongman, A. \& Sereno, J. A. (2014). L2 acquisition and processing of Mandarin tone. In Li, P., Tan, L., Bates, E. \& Tzeng, O. J. L., Handbook of Chinese Psycholinguistics. Cambridge, UK: Cambridge University Press.

[47] Widdowson, H. (1978). Teaching language as communication. London: Oxford University Press.

[48] Xu, K. (2011). A brief introduction to Chinese Language. Nanjing: Nanjing Putong Chubanshe.

[49] Yin, R. K. (2011). Qualitative research from start to finish. New York, NY: The Guildford Press.

[50] Yun, H. (2009). Learn Chinese characters by radicals. Beijing: Huayu Jiaoxue Chubanshe.

[51] Zhang, X. Y. (2011). The Research of Teaching Chinese Characters to Indonesian People. Hunan: Hunan Normal University Master Thesis, 2011. 